\title{
The Role of Consumers' Behaviour in Applying Green Marketing: An Economic Analysis of THE NON-ALCOHOLIC BEVERAGES INDUSTRY IN KOSOVA
}

\author{
Ganimete Podvorica* \\ FATOS UKAJ**
}

\begin{abstract}
KEYWORDS
consumer's environmentally friendly behaviour, trust, green marketing
\end{abstract}

\begin{abstract}
Green marketing in Kosova evolved as a means for enterprises to adjust to increased market competitiveness. The objective of the study was to identify how consumers' environmentally friendly behaviour drove the demand for new ecovalue market offerings. Concurrently, the study aimed to prove how domestic producers of non-alcoholic beverages used their capabilities to deliver new ecovalue market offerings. The research is based on a survey conducted in Kosova. Analysis focused on statistical correlation testing of consumers' green marketing awareness, behaviour toward the environment, information search, trust in advertising and labels displaying health benefits of beverages and attitudes towards a willingness to pay more for organic non-alcoholic beverages compared with nonorganic ones. Significant findings were the positive influence of family and media in shaping consumers' environmentally friendly behaviour and, in contrast, consumers' mistrust in the marketing activities of producers as a consequence of misleading advertising.
\end{abstract}

PhD Candidate of Marketing, University of Prishtina 'Hasan Prishtina', Email: gpodvorica@ * gmail.com, ORCID: https://orcid.org/0000-0002-0716-7685.

** Associate Professor of Marketing, Corresponding author, University of Prishtina 'Hasan Prishtina', Email: fatos.ukaj@uni-pr.edu, ORCID: https://orcid.org/0000-0001-9765-4446. 


\section{INTRODUCTION}

In general, green marketing is defined as 'all activities designed to generate and facilitate any exchanges intended to satisfy human needs or wants, such that the satisfaction of these needs and wants occurs, with minimal detrimental impact on the natural environment'. ${ }^{1}$ New approach considers that 'green marketing facilitates the development and marketing of more sustainable products and services while introducing sustainability efforts into the core of the marketing process and business practices'. ${ }^{2}$

The European Union is committed to a 'high level of consumer protection'. 3 Kosova aspires to join the European Union. The non-alcoholic beverages' industry in Kosova has a substantial role in evolving sustainability and economic growth. Economics, demographics, lifestyle and consumer behaviour towards the environment and food consumption tend to converge within the fragile market of the country. According to the Kosova Green Report, consumption of nonalcoholic beverages ranks as the fifth most consumed food category (9\%), following meat (21\%); milk, eggs and cheese (18\%); bread and cereals $(17 \%)$; and vegetables (12\%). ${ }^{4}$ Environmental challenges the country is facing include mounting waste. Waste from non-alcoholic beverage containers, such as aluminium, plastic and glass, is increasing, and it is damaging the environment. Waste management has not reached the planned collection levels. ${ }^{5}$

While consumers' awareness of the environmental and health impact of food sourcing and processing is on the rise, producers have adapted their production to be more environmentally friendly. Consequently, the non-alcoholic beverages sector is committed to reducing the amount of plastic and glass waste in landfills. Despite limited financial resources, domestic producers of non-alcoholic beverages have begun investing on energy efficiency, production of organic beverages, clean technology, water treatment plants and waste management, and are also taking initiatives for the collection of plastic and glass bottles for recycling. Green marketing practices of producers encompasses promotion of 'green concepts' through marketing communication channels. Focus is on

1 Michael Jay Polonsky, 'An introduction to green marketing' (1994) 1(1) EGJ < https://www. uow.edu.au/ sharonb/STS300/market/green/article2.html> accessed 10 December 2017.

2 Ross Gordon, Marylyn Carrigan, Gerard Hastings, 'A framework for sustainable marketing' (2011) 11(2) $143 \mathrm{MT}<$ https://doi.org/10.1177/1470593111403218> accessed 11 November 2017.

3 Treaty on the Functioning of the European Union (1958) Title XV: Consumer Protection.

4 Ministry of Agriculture, Forestry and Rural Development 'Kosovo Green Report 2017' (2017) GK 15, 181.

5 Ministry of Environment and Spatial Planning 'Strategy on Waste Management 2013-2022' (2013) GK 8, 63. 
promotion of green branding, eco-labelling, the ecosystem, health benefits, quality, product features, recycling, pricing and distribution.

The objective of this study is to identify how consumers' environmentally friendly behaviour drives the demand for new eco-value market offerings. Concurrently, the study aims to prove how domestic producers of non-alcoholic beverages can use their capabilities to deliver new eco-value market offerings. Currently, there is no significant research available in Kosova related to green marketing, the green consumer, green behaviour, green communication, green products and eco-production.

Five hypotheses have been established, based on the literature review, and practically through field research conducted in the country. Hypotheses test correlations between the following variables: (1) green marketing awareness of consumers and purchase of eco-friendly products, (2) producers of non-alcoholic beverages claiming to be environmentally friendly and consumer's trust in labels with regard to health benefits, (3) consumer involvement in environmental protection activities and willingness to pay more for eco-friendly products (natural beverages), (4) the social media effect and the family effect towards environmentally friendly consumer behaviour and (5) the governmental regulatory infrastructure effect and the environmental organisations effect towards environmentally friendly consumer behaviour.

Consumers must be informed in order to gain knowledge for choosing and consuming products that cause minimal environmental damage. There is a need to raise consumers' awareness on environmental issues, sustainability and green marketing in order to influence their purchases of green products. ${ }^{6}$ Consumer doubts still persist about green product performance, exacerbated by the competing views expressed around the benefits of organic food. ${ }^{7}$ Peattie and Collins advised that 'consumers must understand and become sensitized to the linkages between production, consumption and disposal systems, and to the environmental impacts caused by such structures' ${ }^{8}$ Yadak and Pathak argued that 'consumers' intention to buy green products in turn influences their green purchase behavior'. ${ }^{9}$ Price is perceived as a crucial factor in consumers'

6 Anastasios Pagiaslis, Athanasios Krystallis Krontalis, 'Green consumption behavior antecedents: Environmental concern, knowledge, and beliefs' (2014) 31 (5) PM 335, 348 $<$ https://doi.org/10.1002/mar.20698> accessed 22 November 2017.

7 Jill Meredith Ginsberg, Paul Bloom, 'Choosing the right green marketing strategy' (2004) 46 (1) MIT SMJ 79, $84<$ https://sloanreview.mit.edu/article/choosing-the-right-greenmarketingstrategy $>$ accessed 8 January 2018.

8 Ken Peattie, Andrea Collins, 'Guest editorial: perspectives on sustainable consumption' (2009) 33 (2) IJCS 107, $122<$ https://doi.org/10.1111/j.1470-6431.2009.00758.x > accessed 23 February 2018.

9 Rambalak Yadav, Govind Swaroop Pathak, 'Young consumers' intention towards buying green products in a developing nation: Extending the theory of planned behavior' (2016) 135 
consumption choices. The Nielsen Survey Report reveals that willingness to pay extra for sustainable products is lower in North America (42\%) and Europe (40\%) compared to Asia-Pacific (64\%), Latin America (63\%) and the Middle East $(63 \%) .{ }^{10}$ Consumers in Kosova make purchases based more on necessity, rather than based on desire, because of low incomes.

\section{Methodology}

The research method applied in this study has been the quantitative method applied through a questionnaire. The survey was self-administered and was conducted from January 2018 to June 2018, applying random sampling technique. Sampling consisted of 541 respondents from major urban regions of Kosova. The main limitation of this survey was the exclusion of rural zones. The questionnaire contained 45 questions. The majority of the questions were close-ended questions (38) that required respondents to choose responses from amongst those provided. The types of close-ended questions that were most commonly used included: dichotomous, Likert scale and multiple choice. The (7) remaining questions were open-ended questions, requiring respondents to express in their own words their attitudes, preferences and beliefs. The primary data were collected, processed and analysed using the test of significance Pearson correlation coefficient (twotailed) on Statistical Package for the Social Science (SPSS) software (version 20).

\section{LITERATURE REVIEW}

Kilbourne and Beckman were amongst the first authors to review the literature on green marketing published in the English language marketing journals from 1971 to 1997, focusing on 'environmental awareness, green consumer characteristics, corporate attitudes and behaviors towards environmental protection, and legal infrastructure such as public policy frameworks'. ${ }^{11}$ Chamorro, Rubio and Miranda proceed further with reviewing the literature on green marketing from 1993 to 2003 by dividing the literature into five categories:

\footnotetext{
JCP 732, $739<$ https://doi.org/10.1016/j.jclepro.2016.06.120> accessed 11 March 2018.
}

10 Nielsen Survey Report, 'Doing well by doing good increasingly, consumers care about corporate social responsibility, but does concern convert to consumption?' (2014) <http:// www.nielsen.com/content/dam/nielsenglobal/apac/docs/reports/2014/Nielsen-GlobalCorporate-Social-Responsibility-Report-June> accessed 26 March 2018.

11 William Kilbourne, Suzanne Beckmann, 'Review and critical assessment of research on marketing and the environment' (1998) 14 (6) JMM 513, 532. 
green consumer, green communication, concepts and strategies, macro marketing and recycling behaviour. ${ }^{12}$

Chabowski, Mena and Gonzalez-Padron reviewed the literature on sustainability in marketing covering the period from 1958 to 2008. The fundamental themes under review comprise external and internal focus, socioenvironmental emphasis, ethics, legal infrastructure, marketing tools and financial performance. ${ }^{13}$ McDonagh and Prothero through their review of green marketing articles from 1998 to 2013 referred to the past, the present and the future of the sustainable marketing by targeting enterprises that apply green marketing practices along with all other matters related to the macro marketing. ${ }^{14}$

Kumar classified thematic literature on green marketing from 1990 to 2014 within these categories: eco-orientation, green marketing strategies, promotions, retailing and distribution, products, supply chain and other green marketing issues. $^{15}$

Leonidou and Leonidou reviewed literature on environmental marketing from 1969 to 2008, revealing seven dimensions of macro marketing interrelated with environmental marketing and environmental management. ${ }^{16}$ Peattie provided 'a detailed academic study of the relationship between environmental concerns and the principles and practice of marketing by examining how aspects of marketing can be applied to developing and implementing greener strategies as well as how environmental issues must influence marketing decisions' ${ }^{17}$ Papadas, Avlonitis and Marylyn asserted that 'companies are adopting green marketing practices to achieve better business performance. However, no research has yet

12 Antonio Chamorro, Sergio Rubio, Francisco Miranda 'Characteristics of research on green marketing" (2009) 18(4) BSE 223,239 < https://doi.org/10.1002/bse.571 > accessed 5 October 2017.

13 Brian Chabowski, Jeannete Mena, Tracy Gonzalez-Padron, 'The structure of sustainability research in marketing 1958-2008: a basis for future research opportunities' (2011) 39 (1) JAMS 55,70 JM 68, 81 <https://doi.org/10.1007/s11747-010-0212-7 > accessed 19 February 2018.

14 Pierre McDonagh, Andrea Prothero, 'Sustainability marketing research: past, present and future' (2014) 30 JMM 1186,1219 < https://doi.org/10.1080/0267257X.2014.943263> accessed 9 February 2018.

15 Prashant Kumar, 'State of green marketing research over 25 years (1990-2014): Literature survey and classification' (2016) 34(1) MIP 137,158<https://doi.org/10.1108/MIP-03-2015$0061>$ accessed 6 December 2017.

16 Constantinos Leonidou, Leonidas Leonidou 'Research into environmental marketing management: a bibliographic analysis' (2011) 45 (1,2) EJM 68,103<https://doi. org/10.1108/03090561111095603> accessed 10 April 2018.

17 Ken Peattie, 'Environmental marketing management: Meeting the green challenge' (1995) University of Michigan: Pitman Publishing. 
operationalized all the organizational facets that are necessary to become a green marketing oriented company'. ${ }^{18}$

$\mathrm{Lu}$, Bock and Joseph contended that 'green marketing is a philosophy used to develop, practice and communicate environmental missions and that would reflect enterprises reputation and market performance' ${ }^{19}$ Nguyen, Phan, Cao and Nguyen concluded that 'barriers for purchasing of green products involve high price, low availability of the products, low credibility and inadequate information regarding ecological factors within labels'. ${ }^{20}$ The first hypothesis examines consumers' green marketing awareness and their purchasing decisions.

$\mathrm{H}_{1}$ : Consumers' green marketing awareness is correlated to consumers' purchase of eco-friendly products (natural beverages).

Trust is an important determinant that affects food purchase intentions of consumers. Ball, Coelho and Machas argued that the relationship marketing theory has been well supported in the marketing empirical literature and trust has been empirically demonstrated to be an important mediator between corporate activities and consumer loyalty. ${ }^{21}$ Reichheld and Schefter observe that 'Loyalty is still about earning the trust of the right kinds of customers'. ${ }^{22}$ As per Mayer, Davis and Schoorman, three primary factors of trustworthiness that must be taken into consideration are 'perceived benevolence, integrity and ability of the trustee. ${ }^{23}$ Lee, Chang, Cheng and Chen advised that 'food companies that would like to distinguish themselves by marketing their products as organic assume that the organic label tells consumers that the food is healthy'. ${ }^{24}$ The second hypothesis covers the trust level of respondents in advertising.

18 Karlos Konstantinos Papadas, George Avlonitis, Marylyn Carrigan, (2017) 'Green marketing orientation: Conceptualization, scale development and validation' (2017) 80 JBR 236, 246 $<\mathrm{https}$ ://doi.org/10.1016/j.jbusres.2017.05.024> accessed 28 August 2018.

19 Leslie Lu, Dora Bock, Mathew Joseph 'Green marketing: what the Millennials buy", (2013) 34 (1) JBS 3, $10<$ https://doi.org/10.1108/JBS-05-2013-0036 > accessed 1 June 2018.

20 The Ninh Nguyen, Thi Thu Hoai Phan, Tuan Khanh Cao, Hoang Viet Nguyen, 'Green purchase behavior: mitigating barriers in developing countries' (2017) 33 (8) SD 4, $6<$ https:// doi.org/10.1108/SD-04-2017-0064> accessed 11 March 2018.

21 Dwayne Ball, Pedro Simões Coelho, Alexandra Machás 'The Role of Communication and Trust in Explaining Customer Loyalty: An Extension to the ECSI Model' $(2004) 38(9,10)$ EJM 1272, $1293<$ doi.org/10.1108/03090560410548979 > accessed 2 March 2018.

22 Frederick Reichheld, Phil Schefter, 'E-loyalty your secret weapon on the Web' (2000) 78 (4) HBR 105,113

23 Roger Mayer, James Davis, David Shoorman, 'An integrative model of organizational trust' (1995) 20 (3) AMR. 709, 734 <https://doi.org/10.5465/amr.1995.9508080335> accessed 29 May 2018.

24 Hsiao Ching Lee, Chun Tuan Chang, Zhao Hong Cheng, Yen Ting Chen 'Will and organic label always increase food consumption? It depends on food type and consumer differences 
$\mathrm{H}_{2}$ : Consumers' level of trust towards producers of non-alcoholic beverages claiming to be environmentally friendly is correlated to consumers' level of trust in labels displaying health benefits of nonalcoholic beverages.

Prices are another determinant of green marketing. ${ }^{25}$ According to Martenson, 'good decisions are based on what consumers actually do, not what they say they would like to do'. ${ }^{26}$ Consumers can have an influence on pricing strategies of producers and retailers. Kotler and Keller considered that 'consumers may have a lower price threshold below which prices signal inferior or unacceptable quality, as well as an upper price threshold above which prices are prohibitive and the product appears not worth the money'. ${ }^{27}$ The third hypothesis takes the income of respondents into consideration.

$\mathrm{H}_{3}$ : Consumers' participation in environmental protection activities is correlated to consumers' willingness to pay more for eco-friendly products (natural beverages).

Philip Kotler argued that 'marketing tools could be used to change behaviors that were counterproductive' and that 'we could run positive programs to encourage people to exercise and eat healthier foods'. ${ }^{28}$ The fourth and fifth hypotheses take into account the effect of different communication means on influencing consumers' environmentally friendly behaviour.

$\mathrm{H}_{4}$ : The effect of social media on influencing consumers to behave environmentally friendly is correlated with the effect of family on influencing consumers to behave environmentally friendly.

in health locus of control' (2018) 63 FQP $\quad 88, \quad 96<$ https://doi.org/10.1016/j. foodqual.2017.08.002> accessed 28 August 2018.

25 Tim Cooper, 'Slower consumption: Reflections on product life spans and the "throwaway society" (2005) 9 (1,2) JIE 51, $67<$ https://doi.org/10.1162/1088198054084671> accessed 15 December 2017 and Katharina Sammer, Rolf Wüstenhagen 'The influence of eco-labelling on consumer behavior-results of a discrete choice analysis for washing machines' (2006) 15

(3) BSE 185, $199<$ https://doi.org/10.1002/bse.522> accessed 11November 2017.

26 Rita Martenson, 'When is green a purchase motive? Different answers from different selves' (2018) 46 (1) IJRDM 21, 33 <https://doi.org/10.1108/IJRDM-11-2016-0228> accessed 20 July 2018.

27 Philip Kotler, Kevin Lane Keller 'Marketing Management' (2012) 14 ${ }^{\text {th }}$ ed. New Jersey: Pearson Education Prentice Hall 386.

28 Philip Kotler, (2017) 'Philip Kotler: some of my adventures in marketing' (2017) 9(2) JHRM 203, $208<$ https://doi.org/10.1108/JHRM-11-2016-0027> accessed 7 February 2018. 
$\mathrm{H}_{5}$ : The effect of the governmental regulatory framework on influencing consumers to behave environmentally friendly is correlated with the effect of environmental organisations on influencing consumers to behave environmentally friendly.

The Law on Consumer Protection (2004/17) in Kosova has a fundamental role in the protection of consumers' health, environment and economic interests. ${ }^{29}$ Furthermore, the Article 169 of the Treaty on the Functioning of the European Union requests protection of health, safety and economic interests of consumers whilst promoting rights for information, education and organising themselves in order to safeguard their interests. ${ }^{30}$

\section{Data Analysis}

The survey polled 541 respondents in Kosova. The data from the survey was coded and entered in SPSS for processing and statistical analyses such as calculation, interpretation, comparison and evaluation. The data set is presented using descriptive statistics, tables and charts. Categorical data placed respondents into groups (such as gender or work status), summarised numbers of respondents in each group (frequency) and provided percentages of respondents in each group (relative frequency). The presented data using mean, median, mode and range were useful measures for numerical data.

Demographical segmentation according to age, gender, geographic location, occupation, family size and income are presented below. The survey targeted the population of major urban regions in the country. The respondents represent the following urban areas: Prishtine (53\%), Prizren (11.3\%), Besiane (10.8\%), Gjakove (5.3\%), Xerxe (3.6\%), Peje (2.8\%), Fushe Kosove $(2.8 \%)$, Decan (1.9\%), Junik (1.9\%), Rahovec (1.5\%), Malisheve (0.9\%), Dragash $(0.8 \%)$, Drenas (0.6\%), Mitrovice $(0.6 \%)$, Ferizaj (0.6\%), Vushtri $(0.4 \%)$, Therande $(0.4 \%)$, Skenderaj $(0.2 \%)$, Gjilan $(0.2 \%)$ and Obiliq $(0.2 \%)$.

From the total number of respondents who stated their gender, female respondents made up $54.43 \%$ and male respondents $45.57 \%$. The youngest respondent was 16 years old. The oldest respondent was 78 years old. The mean for the age was 37 years, median 34 years, mode 27 years and range 62 years. From the total number of 524 respondents who reported their job status, $78.4 \%$ were employed and $21.6 \%$ were unemployed.

29 Official Gazette of Assembly of Kosovo, Law No.2004/17 'Consumers Protection' (2004) Article 3, Assembly of Kosova.

30 Treaty on the Functioning of the European Union (1958) Title XV: Consumer Protection. 
Occupation is another important variable in marketing. The population in the sample consisted of the following occupations: economists (23\%), lawyers $(10.2 \%)$, students $(10 \%)$, housewives $(4.5 \%)$, handymen $(4.5 \%)$, construction engineers $(3.9 \%)$, civil servants $(3.1 \%)$, nurses $(2.9 \%)$, elementary school teachers $(2.6 \%)$, doctors $(2.4 \%)$, agronomists $(1.8 \%)$, information technology engineers $(1.8 \%)$ psychologists $(1.8 \%)$, waiters $(1.6 \%)$, professors $(1.6 \%)$, managers $(1.6 \%)$, shop assistants $(1.4 \%)$, educators $(1.2 \%)$, dentists $(1 \%)$, high school teachers (1\%) and other occupations (16.9\%).

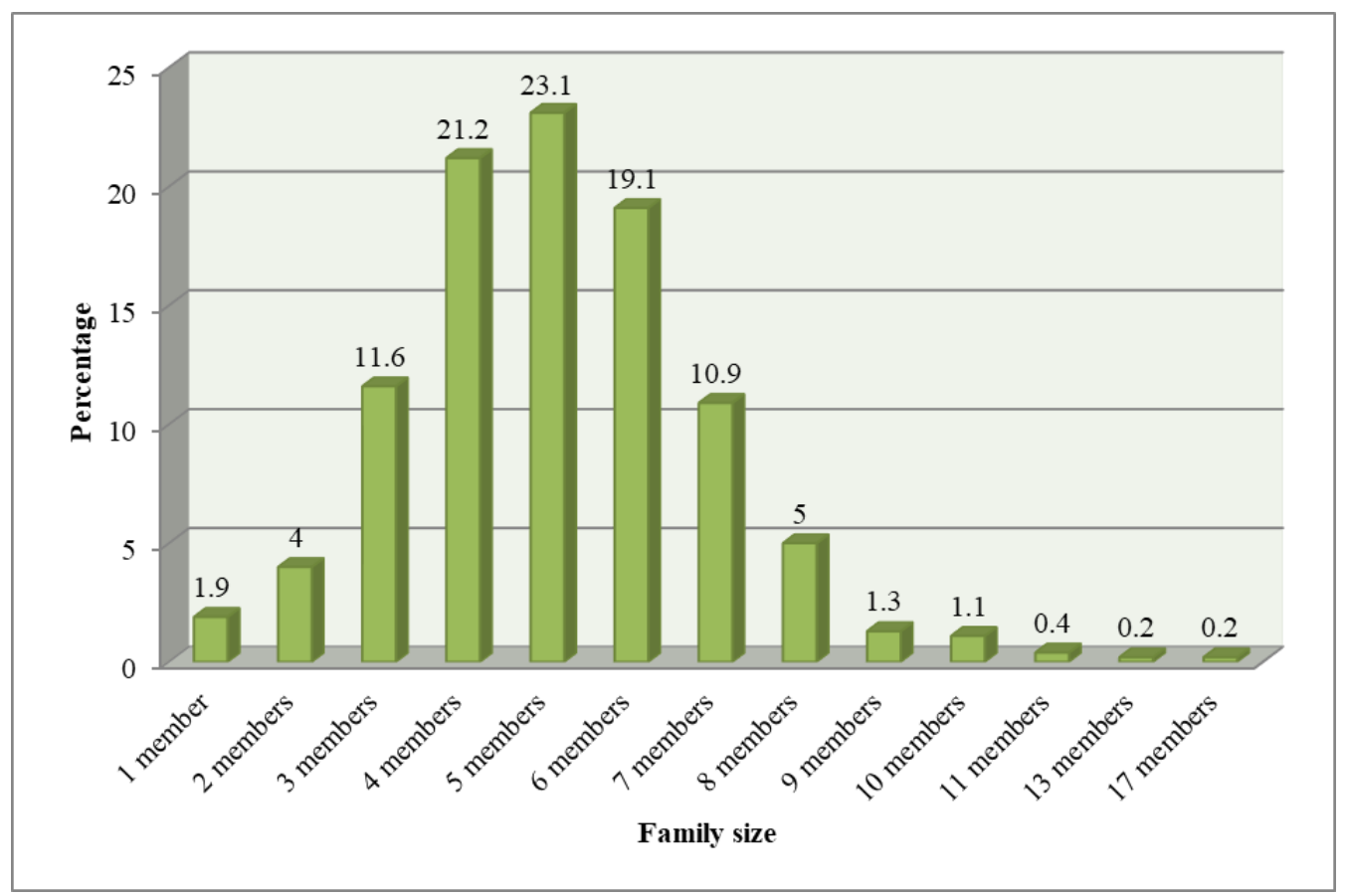

Chart 1: Family size

One of the most important determinants of the consumer's behaviour is the impact of family. It is acknowledged in marketing that family has a great impact on the individual's consumption choices. The survey revealed that family sizes varied from a family with a single member to a large family with as many as 17 family members. Family size was 5 for each: median, mean and mode values. The tradition of having a large family in Albanian society can be traced to ancient times (Podvorica, 2011). Families with 5 members represented $23.1 \%$ of the total of families of respondents, 4 members $(21.2 \%), 6$ members (19.1\%), 3 members (11.6\%), 7 members $(10.9 \%), 8$ members $(5 \%), 2$ members $(4 \%), 1$ member (1.9\%), 9 members $(1.3 \%), 10$ members $(1.1 \%), 11$ members $(0.4 \%), 13$ members $(0.2 \%)$ and 17 members $(0.2 \%)$. Chart 1 exhibits family size variance. Sixty-five respondents did not disclose the size of their families. 
Income has been associated with the willingness to pay more for green products. The lowest reported monthly income was $75 €$ and the highest was $2,300 €$, with a median of $400 €$, a mean of $500 €$ and a mode of $400 €$. Chart 2 presents monthly income of $70 \%$ of respondents as representation of the most frequent reported income amounts. From 338 respondents who disclosed their monthly income, five of the most frequently reported amounts were 49 respondents earned $400 €, 26$ respondents earned $500 €, 23$ respondents earned $450 €, 21$ respondents earned $250 €$ and 19 respondents earned $300 €$.

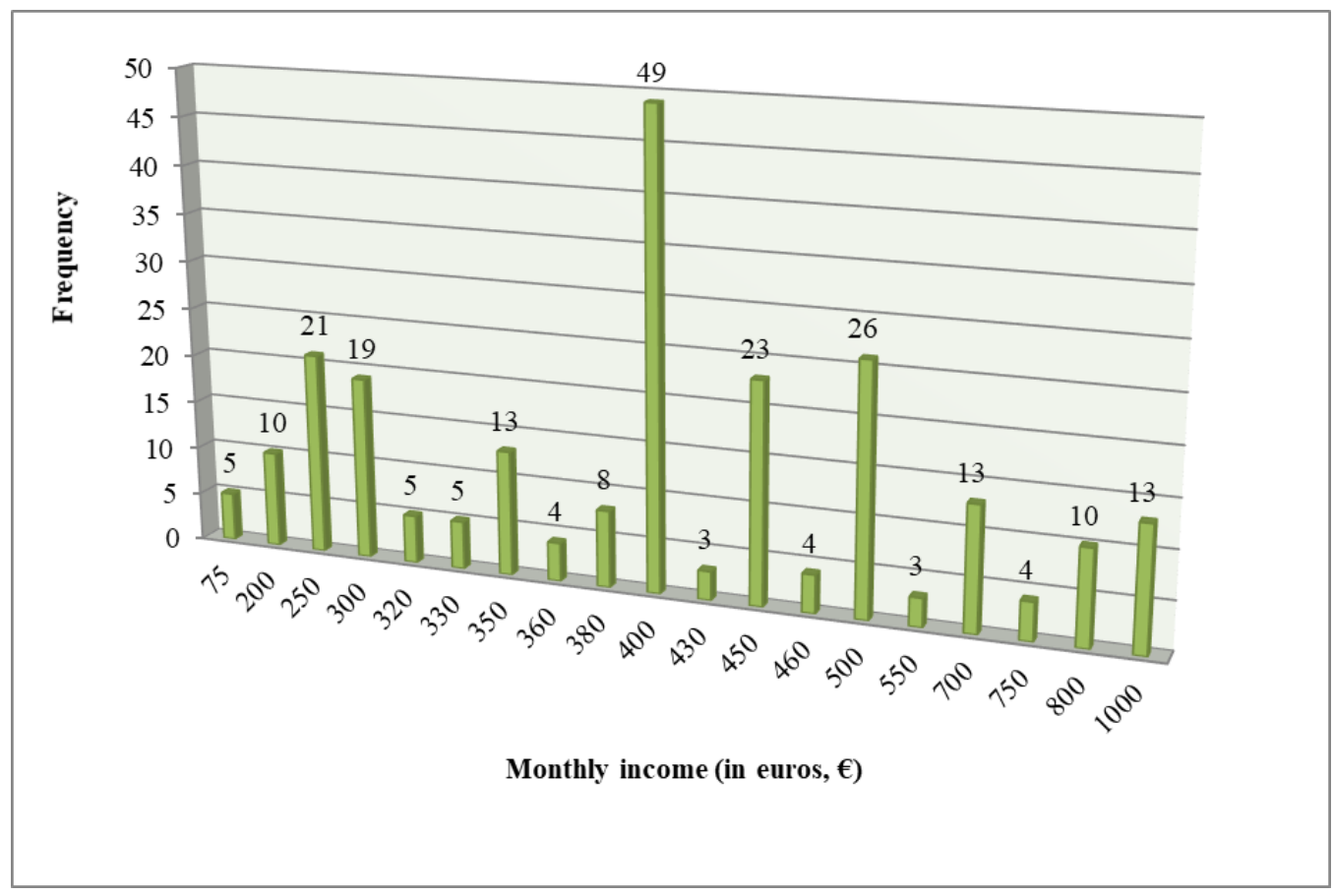

Chart 2: Monthly income (in euros, €)

Respondents who considered that the purchasing of eco-friendly products may contribute to sustainable development accounted for $54.7 \%$, as exhibited on Chart 3. In contrast, $6.4 \%$ of respondents did not believe that the purchasing of eco-friendly products contributed to sustainable development. Moreover, 38.9\% of respondents were undecided regarding the contribution of the purchasing of eco-friendly products on sustainability.

Chart 4 exhibits that green marketing awareness amongst respondents is low (26.2\%). Majority of respondents (43\%) are 'somewhat' aware of green marketing and $30.8 \%$ claim that they are unaware regarding the topic. 


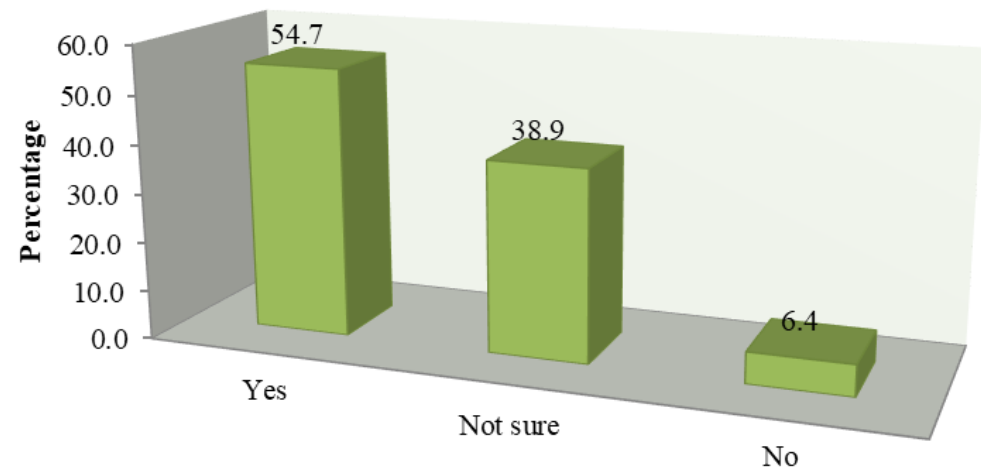

Belief that purchase of eco-friendly products will contribute to sustainable development (Likert Scale)

Chart 3: Purchase of eco-friendly products

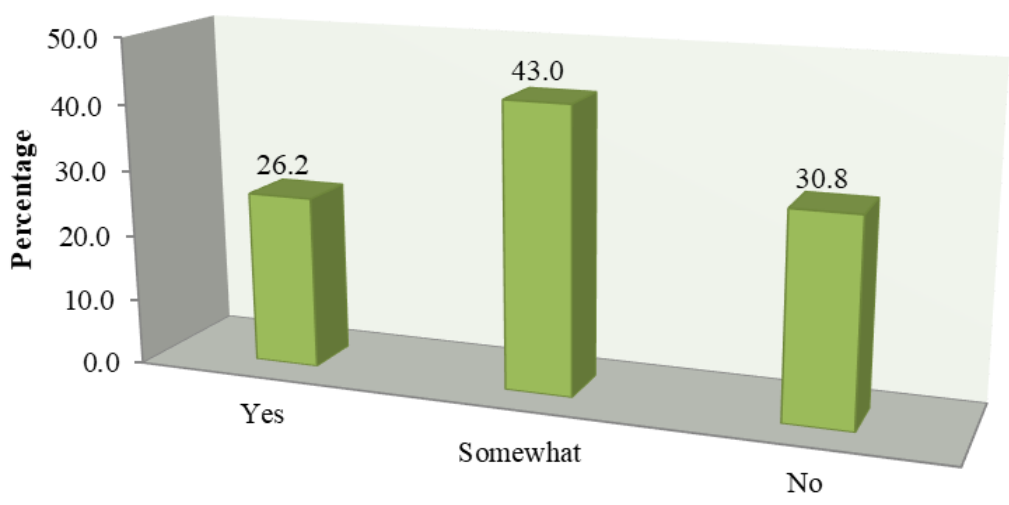

Green marketing awareness (Likert Scale)

Chart 4: Respondents' green marketing awareness

The first hypothesis correlation test is exhibited below in Table 1. The first hypothesis assumed that consumers' green marketing awareness is correlated with consumers' purchase of eco-friendly products (natural beverages). A Pearson correlation coefficient was computed to assess the relationship between the two variables. There was a positive correlation between the two variables, $r=0.215$, $\mathrm{n}=531, \mathrm{p}=0$, inferring that there was a strong positive relationship between respondents having green marketing awareness and respondents purchase of ecofriendly products (natural beverages).

Crosby, Evans and Cowles defined customer trust as 'a belief that the product or service provider can be relied on to behave in such a manner that the long term 
Table 1: First Hypothesis Test

\begin{tabular}{|c|c|c|c|}
\hline \multicolumn{2}{|l|}{ Hypothesis 1} & $\begin{array}{l}\text { Green } \\
\text { marketing } \\
\text { awareness }\end{array}$ & $\begin{array}{l}\text { Purchase of eco-friendly } \\
\text { products (natural beverages) }\end{array}$ \\
\hline \multirow{3}{*}{$\begin{array}{l}\text { Green marketing } \\
\text { awareness }\end{array}$} & $\begin{array}{l}\text { Pearson } \\
\text { correlation }\end{array}$ & 1 & $.215^{* *}$ \\
\hline & $\begin{array}{l}\text { Significance } \\
\text { (two-tailed) }\end{array}$ & & 0 \\
\hline & $\mathrm{N}$ & 539 & 531 \\
\hline \multirow{3}{*}{$\begin{array}{l}\text { Purchase of eco- } \\
\text { friendly products } \\
\text { (natural beverages) }\end{array}$} & $\begin{array}{l}\text { Pearson } \\
\text { Correlation }\end{array}$ & $.215^{* *}$ & 1 \\
\hline & $\begin{array}{l}\text { Significance } \\
\text { (two-tailed) }\end{array}$ & 0 & \\
\hline & $\mathrm{N}$ & 531 & 532 \\
\hline
\end{tabular}

interests of the consumers will be served' ${ }^{31}$ Pursuant to Article 3, paragraph 3.3 of the Kosova Administrative Instruction (MH) No.12/2005 on the Labeling of Food Products, 'Labeling and used methods should not be such as to present the food product with special nourishing features, which attribute to it preventing features and treating of diseases, or refer to other features when the food product really does not contain them. Exemptions to this rule are the natural mineral waters'. ${ }^{32}$

Respondents were asked to state their trust in advertising regarding health benefits of non-alcoholic beverages using communication channels such as television, press and social media. The $16.7 \%$ of respondents stated that they trust advertising related to health benefits of non-alcoholic beverages. On the other hand, $21.4 \%$ respondents claimed that they do not trust advertising of health benefits of non-alcoholic beverages. The majority of respondents $(61.9 \%)$ leaned, to some extent, towards trusting advertising of health benefits of non-alcoholic beverages.

The number of domestic producers of non-alcoholic beverages that claim to be environmentally friendly is increasing. Therefore, respondents were asked to rank producers that claim to be environmentally friendly based on their trustworthiness. Chart 5 exhibits that the majority (60.9\%) of respondents is

31 Lawrence Crosby, Kenneth Evans, Deborah Cowles, 'Relationship quality in services selling: an interpersonal influence perspective' (1990) 54 (3) JM 68, 81 <www.jstor.org/ stable/1251817> accessed 19 February 2018.

32 Ministry of Health, 'Administrative Instruction MSH 12/2005 on Labeling of Food Products' (2005) Article 3, GoK 17. 


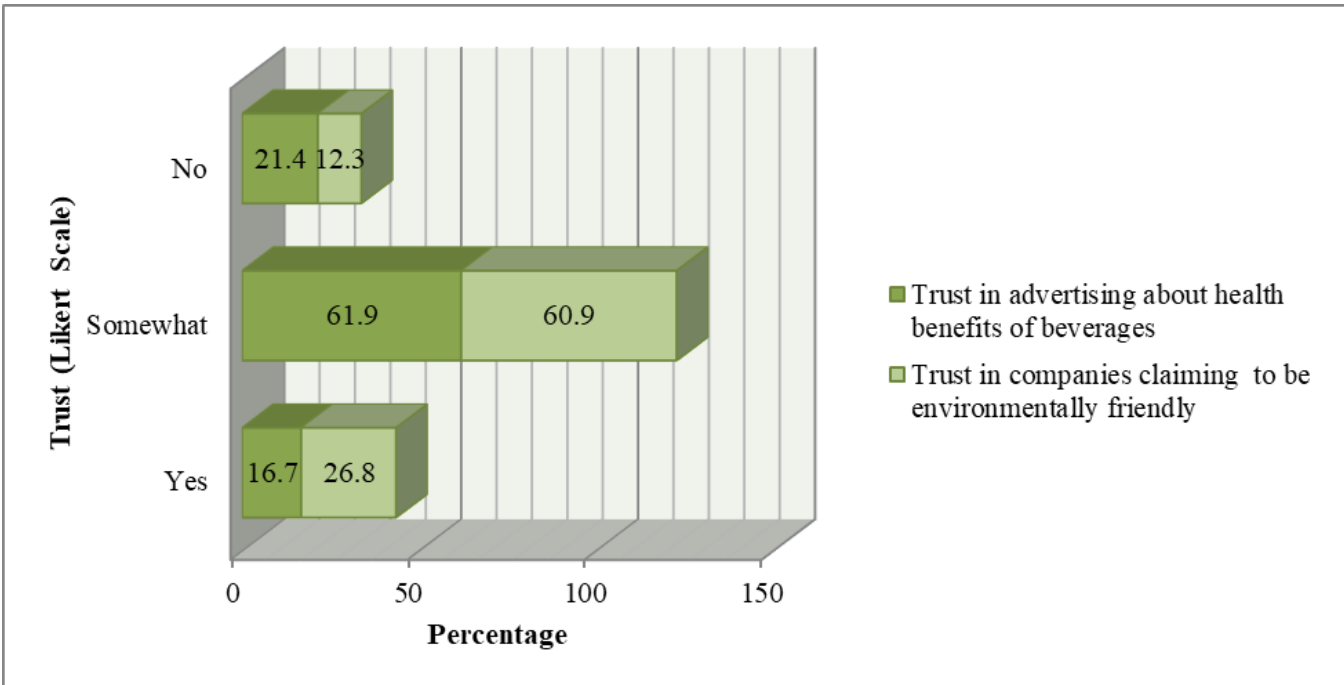

Chart 5: Respondents' trust in advertising concerning health benefits of non-alcoholic beverages versus respondents' trust in producers claiming to be environmentally friendly.

Table 2: Second Hypothesis Test

\begin{tabular}{|c|c|c|c|}
\hline \multicolumn{2}{|l|}{ Hypothesis 2} & $\begin{array}{l}\text { Trust in producers claiming } \\
\text { to be environmentally } \\
\text { friendly }\end{array}$ & $\begin{array}{l}\text { Trust in advertising } \\
\text { concerning health } \\
\text { benefits of beverages }\end{array}$ \\
\hline \multirow{3}{*}{$\begin{array}{l}\text { Trust in producers } \\
\text { claiming to be } \\
\text { environmentally } \\
\text { friendly }\end{array}$} & $\begin{array}{l}\text { Pearson } \\
\text { correlation }\end{array}$ & 1 & $.115^{* *}$ \\
\hline & $\begin{array}{l}\text { Significance } \\
\text { (two-tailed) }\end{array}$ & & .008 \\
\hline & $\mathrm{N}$ & 529 & 524 \\
\hline \multirow{3}{*}{$\begin{array}{l}\text { Trust in advertising } \\
\text { concerning health } \\
\text { benefits of beverages }\end{array}$} & $\begin{array}{l}\text { Pearson } \\
\text { correlation }\end{array}$ & $.115^{* *}$ & 1 \\
\hline & $\begin{array}{l}\text { Significance } \\
\text { (two-tailed) }\end{array}$ & .008 & \\
\hline & $\mathrm{N}$ & 524 & 533 \\
\hline
\end{tabular}

neutral to these claims. The $12.3 \%$ of the respondents did not trust these claims. The $26.8 \%$ of the respondents expressed trust in producers' claims of being environmentally friendly.

The second hypothesis test results are exhibited in Table 2. The second hypothesis assumed that consumers' level of trust towards producers of nonalcoholic beverages claiming to be environmentally friendly is correlated with consumers' level of trust in labels displaying the health benefits of non-alcoholic beverages. A Pearson correlation coefficient was computed to assess the relationship between two variables. There was a positive correlation between the 
two variables, $\mathrm{r}=0.115, \mathrm{n}=524$ and $\mathrm{p}=0.008$, inferring a strong positive relationship between respondents' level of trust towards producers of nonalcoholic beverages claiming to be environmentally friendly and respondents' level of trust in labels displaying health benefits of non-alcoholic beverages.

Participation in environmental protection activities is an important factor related to consumer behaviour and green marketing. Chart 6 displays respondents' answers related to participation in environmental protection activities. The majority of housewives $(95 \%)$ stated that they did not participate in environmental protection activities. Also, percentages of respondents who did not participate in such initiatives are listed in descending order and categorised by their occupations: educators $(83 \%)$, dentists $(80 \%)$, shop assistants $(71 \%)$, elementary school teachers $(69 \%)$, information technology engineers $(67 \%)$, professors $(63 \%)$, high school teachers $(60 \%)$, lawyers $(52 \%)$, economists $(50 \%)$ and doctors $(42 \%)$. Respondents who were more active with environmental protection programmes and activities are categorised by occupation and listed in descending order: waiters $(75 \%)$, cashiers (75\%), psychologists $(67 \%)$, agronomists $(62 \%)$, managers $(60 \%)$, civil servants $(57 \%)$, construction engineers $(53 \%)$, students (53\%), economists (50\%) and nurses (50\%).

Article 2 of the Administrative Direction (MH) No.12/2005 on Labeling of Food Products issued by the Government of Kosova, Ministry of Health, defines labelling as 'any text written, stamped or any graphical presentation that stands on the label, accompanies the product or is placed next to it to stimulate sale'. Moreover, Article 3, paragraph 3.1 of the Administrative Direction (MH) No.12/2005 on Labeling of Food Products states that 'the label placed on the goods packaging should not present the goods in a wrong way, falsely or to create a wrong impression about its real nature, with the purpose of deceiving the consumers'.

Furthermore, the EU Directive 2006/114/EC, Article 2(b) clarifies that 'misleading advertising means any advertising which in any way, including its presentation, deceives or is likely to deceive the persons to whom it is addressed or whom it reaches and which, by reason of its deceptive nature, is likely to affect their economic behavior or which, for those reasons, injures or is likely to injure a competitor'. ${ }^{33}$ It is imperative to reveal to what extent producers are informing, engaging and energising their consumers through marketing campaigns in order to determine the degree of trust that consumers' have in eco-friendly claims on labels.

33 Official Journal of the European Union (2006) 'Directive 2006/114/EC of the European Parliament and of the Council of 12 December 2006 concerning misleading and comparative advertising (codified version) < https://eur-lex.europa.eu/eli/dir/2006/114/oj> accessed 3 June 2018. 


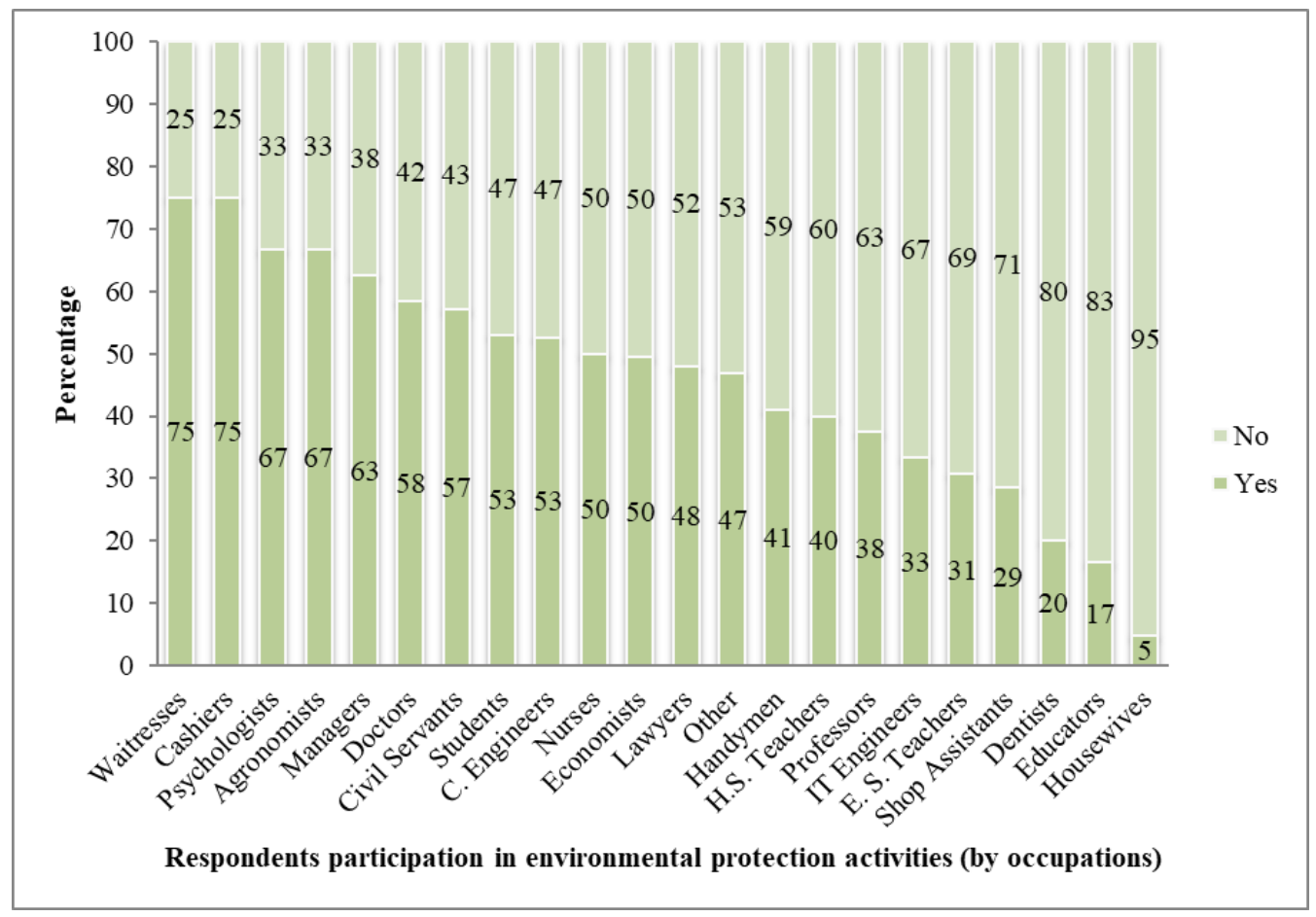

Chart 6: Participation in environment protection activities

Chart 7 shows that $43.8 \%$ of respondents have been exposed to green marketing campaigns. On the other hand, $22.9 \%$ of respondents had not noticed green marketing campaigns, whereas $33.1 \%$ of respondents are unsure as to their exposure to green marketing campaigns.

Respondents' trust in labels is shown in Chart 8. The following list ranks respondents based on their degree of trust for product labels: very often $(23 \%)$, often $(37.5 \%)$, rarely $(20.2 \%)$, very rarely $(12.6 \%)$ and never $(6.6 \%)$.

Kaplan, Gelioni and Reed (2018) argued that 'many communities use promotion in regards to the sustainable purchasing, but there is no conceptual understanding of the right price required to be set for green products'. ${ }^{34}$ The survey aimed to determine the number of respondents who were ready to pay more for natural non-alcoholic beverages and to reveal the highest amount of premium that respondents were willing to pay for a product. The data exhibited in Chart 9 reveal that $39.61 \%$ of respondents, with $20.58 \%$ female respondents and $19.03 \%$ male respondents, were willing to recognise quality, sustainability and origin (e.g. domestic over foreign products) and pay a premium for natural non-alcoholic beverages compared with the processed non-alcoholic beverages.

34 Brent Kaplan, Brett Gelioni, Derek Reed, 'A behavioral economic approach to green consumerism: Demand for reusable shopping bags' (2018) 27 BSI 20, $30<$ https://doi. org/10.5210/bsi.v27i0.8003> accessed 11 August 2018. 


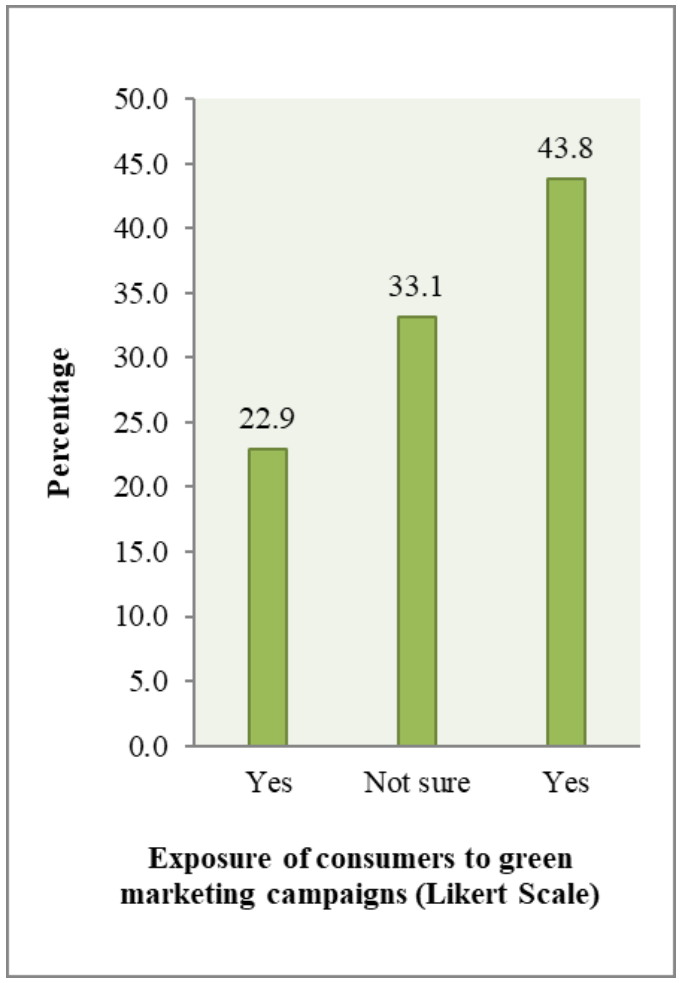

Chart 7: Exposure to green marketing campaign

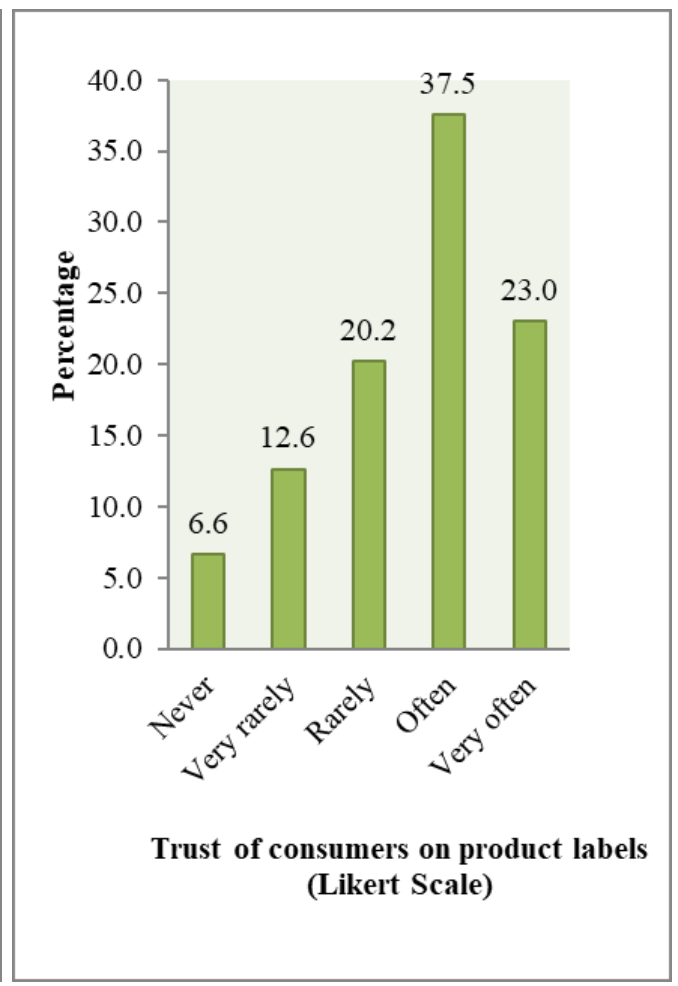

Chart 8: Trust in product labels

Also, there is no significant variance between genders when it comes to the number of respondents $(25.17 \%)$ who reflect price sensitivity and unwillingness to pay extra for natural non-alcoholic beverages compared with processed nonalcoholic beverages (13.2\% female respondents and $11.07 \%$ male respondents). From a total of $36.12 \%$ respondents who were "somewhat" willing to pay more for natural non-alcoholic natural beverages, there is a gender gap with female respondents making up $20.97 \%$ and male respondents at $15.15 \%$.

The results show that the majority of respondents $(61.29 \%)$ were either unwilling to pay more $(25.17 \%)$ or indifferent $(36.12 \%)$ about paying extra for eco-friendly products (non-alcoholic natural beverages).

Chart 10 exhibits that amongst respondents (39.61\%) who were willing to pay a premium, the level of the premium varied as shown below:

a. $56.3 \%$ of respondents were willing to pay from $3 \%$ up to $5 \%$ more for eco-friendly features of the natural beverages,

b. $36.3 \%$ of respondents were willing to pay from $6 \%$ up to $10 \%$ more for eco-friendly features of the natural beverages, and

c. $7.4 \%$ of respondents were willing to pay from $11 \%$ up to $20 \%$ more for eco-friendly features of the natural beverages. 


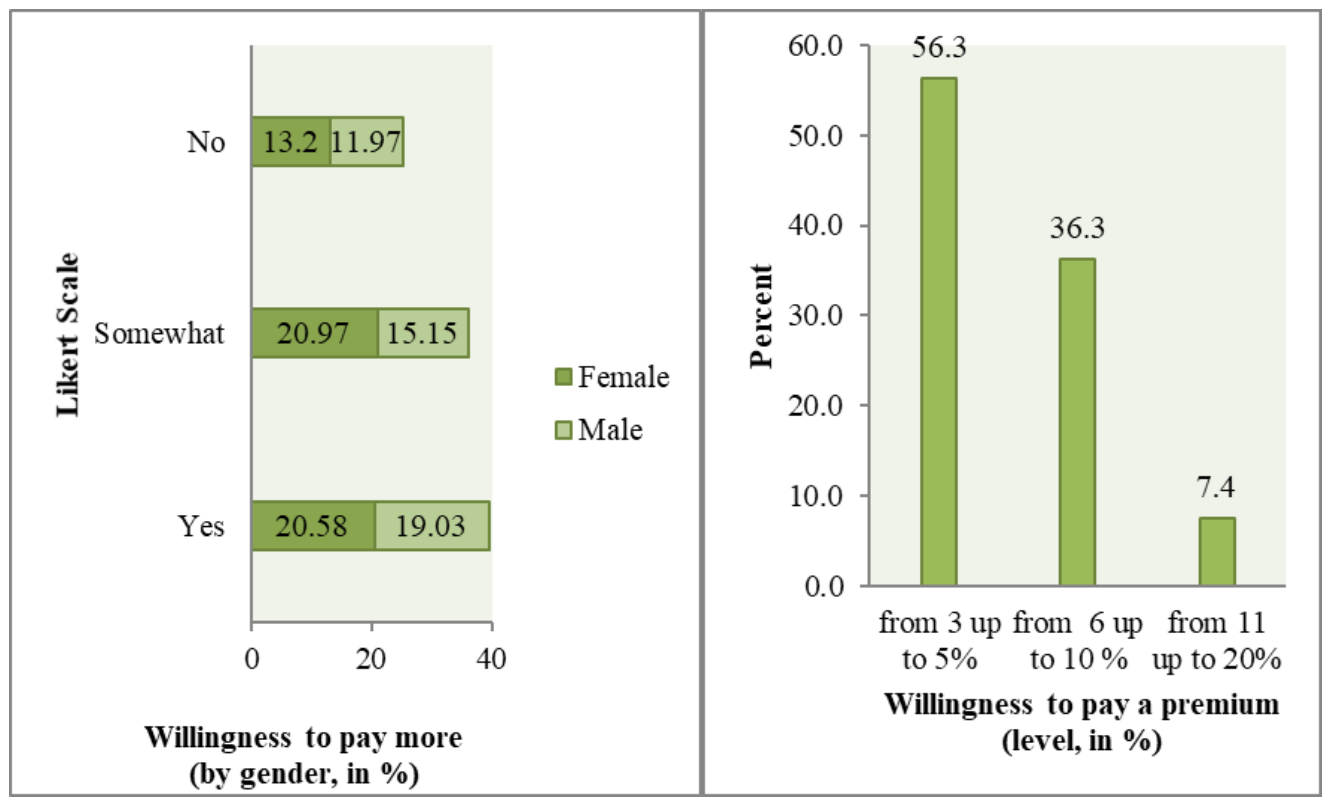

Chart 9: Consumers' willingness to pay more

Chart 10: Level of premium consumers are willing to pay

Table 3: Third Hypothesis Test

\begin{tabular}{|l|l|l|l|}
\hline \multicolumn{2}{|l|}{ Hypothesis 3} & $\begin{array}{l}\text { Participation in } \\
\text { environment } \\
\text { protection activities }\end{array}$ & $\begin{array}{l}\text { Willingness to pay more for } \\
\text { eco-friendly products } \\
\text { (natural beverages) }\end{array}$ \\
\hline \multirow{3}{*}{$\begin{array}{l}\text { Participation in } \\
\text { environment protection } \\
\text { activities }\end{array}$} & $\begin{array}{l}\text { Pearson correlation } \\
\text { Significance } \\
\text { (two-tailed) }\end{array}$ & 1 & $.135^{* *}$ \\
\cline { 2 - 5 } & $\mathrm{N}$ & 534 & .002 \\
\hline \multirow{3}{*}{$\begin{array}{l}\text { Willingness to pay more } \\
\text { for eco-friendly products } \\
\text { (natural beverages) }\end{array}$} & $\begin{array}{l}\text { Significance } \\
\text { (two-tailed) }\end{array}$ & .002 & 517 \\
\cline { 2 - 5 } & $\mathrm{N}$ & 517 & 1 \\
\hline \multirow{2}{*}{$* *$ Correlation is significant at the.01 (two-tailed). } & 522 \\
\hline
\end{tabular}

Table 3 summarises the third hypothesis. The third hypothesis assumed that consumers' participation in environmental protection activities is correlated with consumers' willingness to pay more for eco-friendly products (natural beverages). A Pearson correlation coefficient was computed, and it was determined that there is a positive linear correlation between the two variables, $\mathrm{r}=0.135, \mathrm{n}=517, \mathrm{p}=$ 0.002. Generally, there was a strong positive relationship between consumers' participation in environmental protection activities and consumers' willingness to pay more for eco-friendly products (natural beverages). 
The consumer's buying decision process begins when the consumer recognises the need for the product. The second step in the decision process involves information search. Consumers' personal experiences with certain products or services are remembered and may be recalled easily, especially if it involves regular or frequent purchase of a particular product. On the other hand, if the consumer had no first-hand experience or previous information for the product, internal or external information search is necessary. Consumers then seek information from family, friends, social media, salespeople, retailers, producers, media and variety of sources on the Internet (e.g. online reviews and reports).

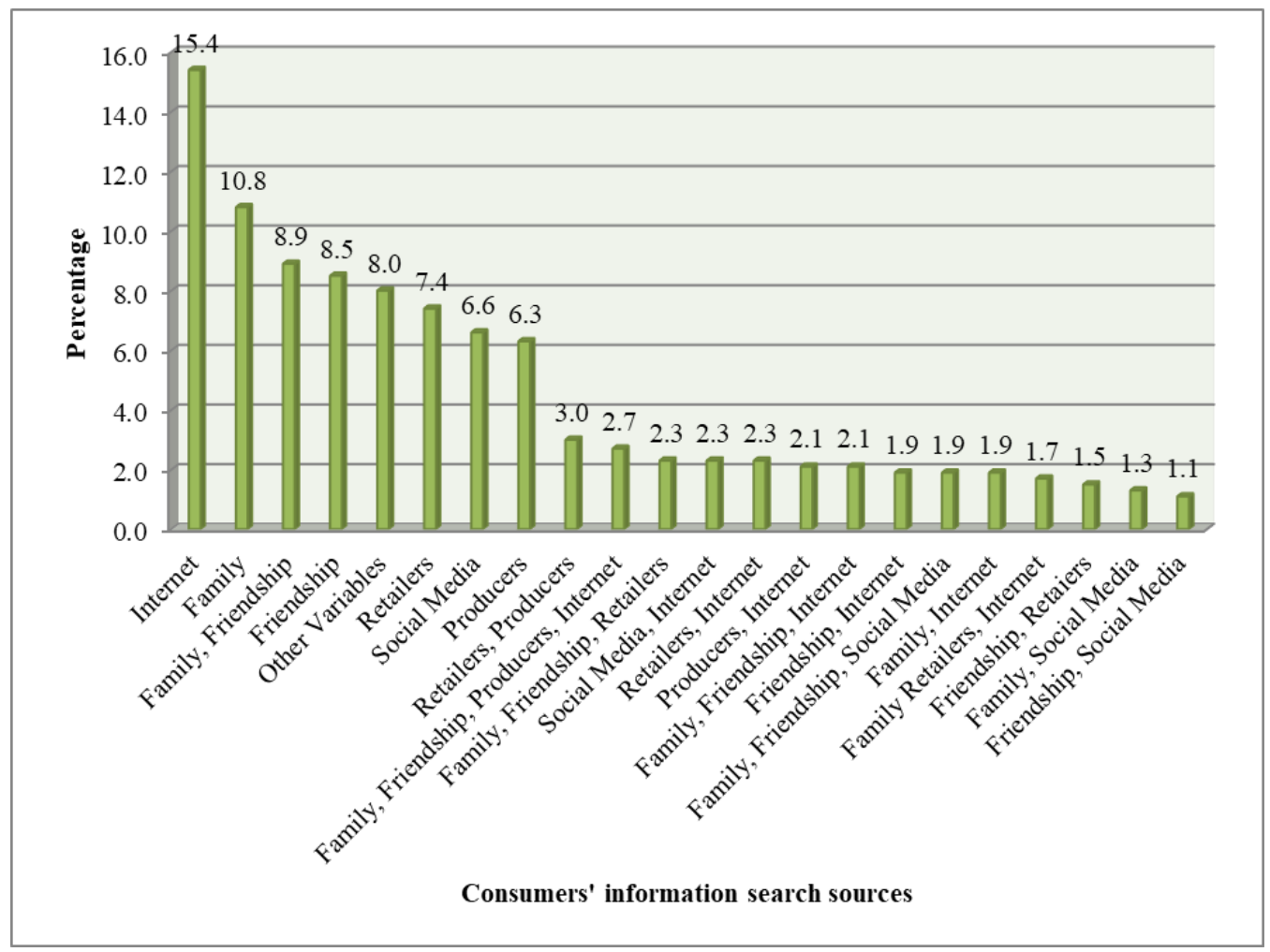

Chart 11: Consumers' information search for the purchasing of non-alcoholic beverages

The data presented in Chart 11 reveal that the most preferred information channel for respondents is the Internet, indicating usage of $15.4 \%$. In addition, Internet usage widened to a total of $32.3 \%$ when considered in combination with, or as a facilitator of, other channels of information search, such as social media and the Internet (2.3\%); friends and the Internet (1.9\%); family, retailers and the Internet (1.7\%); retailers and the Internet (2.3\%); family and the Internet (1.9\%); producers and the Internet (2.1\%); family, friendship, producers and the Internet $(2.7 \%)$; and family, friends and the Internet (2.1\%). 
After the Internet, family came in the second place (10.8\%) followed by friends $(8.5 \%)$ as providers of information. Family and friends as joint sources of information made up $8.9 \%$. Altogether, family and friends, considered separately and jointly, accounted as sources of information for $28.2 \%$ respondents and ranked high as sources of information for consumers.

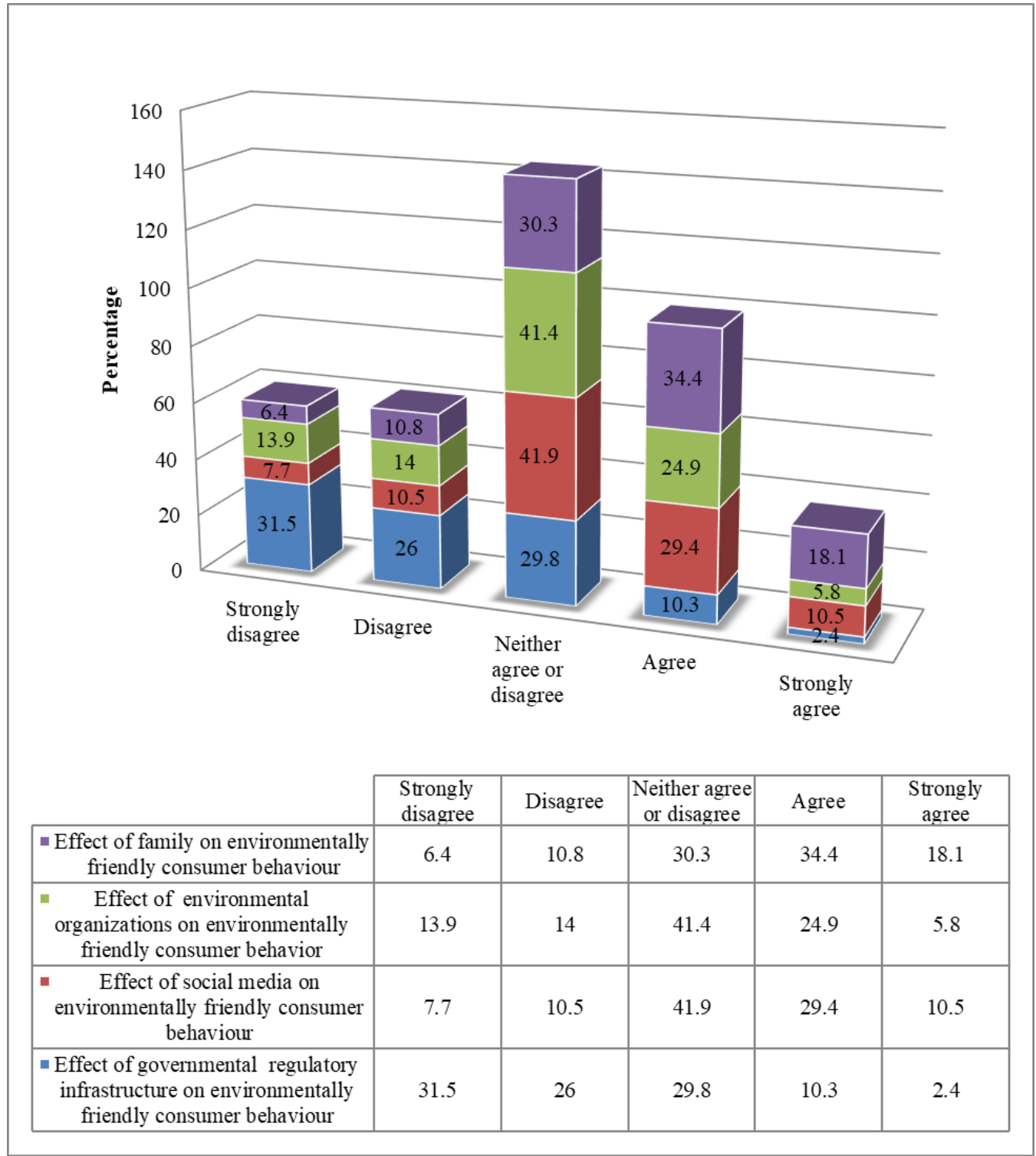

Chart 12: Statements on environmentally friendly consumer behaviour

Responders who considered retailers as the source of information made up $7.4 \%$. Producers were the source of information for $6.3 \%$ of respondents. Social media was a source of information for $6.6 \%$ of respondents. 
Chart 12 shows the data derived from the four survey statement questions to determine the influence on encouraging environmentally friendly consumer behaviour from the family, social media, environmental organisations and the regulatory infrastructure.

In our daily life, we communicate and share a variety of experiences with family and friends. Communication may be favourable or unfavourable and experiences may be satisfactory or unsatisfactory. As the communication is a two way process consisting of sending and receiving messages, word-of-mouth communication is an approach aimed at using personal recommendations and referrals for goods, services, ideas, behaviours and many other experiences. The effect of word-of-mouth communication with family and friends seems to have a strong influence on environmentally friendly consumer behaviour. As Chart 12 exhibits, for $52.5 \%$ of consumers, their behaviour towards the environment is affected positively through communication with family and friends (i.e. $34.4 \%$ of consumers agreed with this qualification and $18.1 \%$ strongly agreed).

The use of social media and the Internet has increased as a means for creating and sharing information, thoughts, ideas and relationships online. The Internet provides a variety of information and facilitates communication globally. As people engage with each other on social media sites, there is an opportunity for them to communicate in real-time via audio, text, images and video, and it is assumed that it can have a positive effect on influencing friendly consumer behaviour towards the environment. In this aspect, social media and the Internet were the second greatest influencers of consumers' environmentally friendly behaviour, with a total of $39.9 \%$ respondents agreeing with this qualification (29.4\% agreed and $10.5 \%$ strongly agreed).

Table 4 summarises the results of the fourth hypothesis. The fourth hypothesis assumed that the effect of social media on influencing consumers to behave in an environmentally friendly manner is correlated with the effect of family on influencing consumers to behave in an environmentally friendly manner. A Pearson correlation coefficient revealed that there was a positive correlation between the two variables, $r=0.462, n=533, p=0$. Generally, there was a strong positive relationship between the effect of social media on influencing consumers to behave environmentally friendly and the effect of family on influencing consumers to behave environmentally friendly.

Many different environmental actions can address specific behaviours, processes and activities that can easily be incorporated within national legislation and regulations and can have far reaching effects. Initiatives on a national level, such as gathering and recycling of plastic and glass bottles, water conservation, investing and using of renewable energy and measures towards ecosystem protection, are some examples of environmental actions as a means to encourage environmentally friendly behaviour and to promote sustainable behaviour. The 
Table 4: Fourth Hypothesis Test

\begin{tabular}{|c|c|c|c|}
\hline \multicolumn{2}{|l|}{ Hypothesis 4} & $\begin{array}{l}\text { Effect of social media } \\
\text { on environmentally } \\
\text { friendly consumer } \\
\text { behaviour }\end{array}$ & $\begin{array}{l}\text { Effect of family on } \\
\text { environmentally } \\
\text { friendly consumer } \\
\text { behaviour }\end{array}$ \\
\hline \multirow{3}{*}{$\begin{array}{l}\text { Effect of social media on } \\
\text { environmentally friendly } \\
\text { consumer behaviour }\end{array}$} & Pearson correlation & 1 & $.462^{* *}$ \\
\hline & $\begin{array}{l}\text { Significance } \\
\text { (two-tailed) }\end{array}$ & & 0 \\
\hline & $\mathrm{N}$ & 534 & 533 \\
\hline \multirow{3}{*}{$\begin{array}{l}\text { Effect of family on } \\
\text { environmentally friendly } \\
\text { consumer behaviour }\end{array}$} & Pearson correlation & $.462^{* *}$ & 1 \\
\hline & $\begin{array}{l}\text { Significance } \\
\text { (two-tailed) }\end{array}$ & 0 & \\
\hline & $\mathrm{N}$ & 533 & 535 \\
\hline \multicolumn{3}{|c|}{ ** Correlation is significant at the .01 (two-tailed). } & \\
\hline
\end{tabular}

majority of respondents $(87.3 \%)$ felt very reluctant about the effectiveness of national environmental legislation, regulatory infrastructure, action plans, strategies or policies towards the encouragement of environmentally friendly behaviour. Only $12.7 \%$ of respondents perceived the government and its legislation, policies and strategies as being effective means for influencing environmentally friendly behaviour.

Environmental organisations are committed to a sustainable future and to improving the social, economic and environmental well-being of the community by creating a clean and safe place to live, by improving environmental quality, by delivering lessons on managing resources effectively and efficiently, by promoting reuse and recycling and by constructively challenging and encouraging each other to do better in order to deliver values to the entire society. The effect of environmental initiatives, programmes and activities are perceived to have an impact on motivating environmentally friendly behaviour for $30.7 \%$ of respondents. The $41.9 \%$ of respondents do not agree with this statement.

Table 5 summarizes the results of the fifth hypothesis. The fifth hypothesis assumed that the effect of the governmental regulatory framework on influencing consumers to behave in an environmentally friendly way is correlated with the effect of environmental organizations on influencing consumers to behave in an environmentally friendly manner. A Pearson correlation coefficient was computed to assess the relationship between the two variables. There was a positive correlation between the two variables, $\mathrm{r}=0.484, \mathrm{n}=534, \mathrm{p}=0$. There was also a strong positive relation between the effect of the governmental regulatory framework on influencing consumers to behave in an environmentally friendly manner and the effect of environmental organisations on influencing consumers to behave environmentally friendly. 
Table 5: Fifth Hypothesis Test

\begin{tabular}{|c|c|c|c|}
\hline \multicolumn{2}{|l|}{ Hypothesis 5} & $\begin{array}{l}\text { Effect of governmental } \\
\text { regulatory } \\
\text { infrastructure on } \\
\text { environmentally } \\
\text { friendly consumer } \\
\text { behaviour }\end{array}$ & $\begin{array}{l}\text { Effect of } \\
\text { environmental } \\
\text { organisations on } \\
\text { environmentally } \\
\text { friendly consumer } \\
\text { behaviour }\end{array}$ \\
\hline \multirow{3}{*}{$\begin{array}{l}\text { Effect of governmental } \\
\text { regulatory infrastructure on } \\
\text { environmentally friendly } \\
\text { consumer behaviour }\end{array}$} & Pearson correlation & 1 & $.484^{* *}$ \\
\hline & $\begin{array}{l}\text { Significance } \\
\text { (two-tailed) }\end{array}$ & & 0 \\
\hline & $\mathrm{N}$ & 534 & 534 \\
\hline \multirow{3}{*}{$\begin{array}{l}\text { Effect of environmental } \\
\text { organisations on } \\
\text { environmentally friendly } \\
\text { consumer behaviour }\end{array}$} & Pearson correlation & $.484^{* *}$ & 1 \\
\hline & $\begin{array}{l}\text { Significance } \\
\text { (two-tailed) }\end{array}$ & 0 & \\
\hline & $\mathrm{N}$ & 534 & 534 \\
\hline
\end{tabular}

\section{CONCLUSIONS AND RECOMMENDATIONS}

The consumer is demanding new eco-value market offerings by judging the offerings based on a variety of elements such as product features, quality, origin, taste, price, packing, labelling, performance, durability, services or any environmental features that might satisfy their need. Thus, alongside the growth of awareness on environmental concerns worldwide, the core benefit is to establish the environmentally friendly behaviour of consumers, which, in turn, serves as an incentive to encourage the environmentally friendly behaviour of producers. Statistical hypothesis tests have shown that there are linear positive correlations for all (five) hypotheses. Strikingly, the data revealed mistrust of respondents in the marketing activities of producers. Therefore, domestic producers of non-alcoholic beverages have to be careful with their promotions and should integrate environmental criteria within their strategic planning and honestly communicate their efforts when aiming to deliver new eco-value market offerings. The remaining challenge for producers is designing ethical green marketing communication mix platforms that are mandatory for a direct dialogue and to build trust with consumers, especially where green marketing activities are concerned. In addition, government has to enforce laws regarding the protection of consumers from misleading advertisement.

Findings also revealed that word of mouth communication (family and friends) and social media and the Internet are effective channels of communication to positively influence consumers' environmentally friendly behaviour. Notably, the governmental legislature and executives are perceived as being significantly less effective when persuading consumers with as to their legislative means. 
Similarly, environmental organisations have shown poor performance in relation to the implementation of environmental programs, activities and campaigns to alert people to the severity of the problem. Hence, the Ministry of Education, the Ministry of Environment, the Ministry of Trade and Industry, the Ministry of Health, the Agency for Environment Protection, the Food and Veterinary Agency and environmental organisations shall apply the multifaceted approach to the lifetime value of consumers' perceptions and trust regarding environmentally friendly behaviour. National environmental action plans, consumer protection programmes and consumers' health protection programmes should be advanced to encourage the consumers' environmentally friendly behaviour in the short and long terms.

\section{References}

Ball Dwayne, Coelho Pedro Simões, Machás Alexandra 'The Role of Communication and Trust in Explaining Customer Loyalty: An Extension to the ECSI Model' $(2004) 38$ (9, 10) EJM 1272, 1293 < doi.org/10.1108/03090560410548979 > accessed 2 March 2018.

Crosby Lawrence, Evans Kenneth, Cowles Deborah, 'Relationship quality in services selling: an interpersonal influence perspective' (1990) 54 (3) JM 68, 81 < www.jstor.org/ stable/1251817> accessed 19 February 2018.

Chabowski Brian, Mena Jeannete, Gonzalez-Padron Tracy, 'The structure of sustainability research in marketing 1958-2008: a basis for future research opportunities' (2011) 39 (1) JAMS 55, $70 \mathrm{JM}<$ https://doi.org/10.1007/s11747-010-0212-7 > accessed 19 February 2018.

Chamorro Antonio, Rubio Sergio, Miranda Francisco 'Characteristics of research on green marketing" (2009) 18(4) BSE 223, $239<$ https://doi.org/10.1002/bse.571 > accessed 5 October 2017.

Cooper Tim 'Slower consumption: Reflections on product life spans and the "throwaway society" (2005) 9 (1, 2) JIE 51, 67 < https://doi.org/10.1162/1088198054084671> accessed 15 December 2017.

Gordon Ross, Carrigan Marylyn, Hastings Gerard, 'A framework for sustainable marketing' (2011) 11(2) MT 143, $163<$ https://doi.org/10.1177/1470593111403218> accessed 11 November 2017.

Ginsberg Jill Meredith, Bloom Paul, 'Choosing the right green marketing strategy' (2004) 46 (1) MIT SMJ 79, $84<$ https://sloanreview.mit.edu/article/choosing-the-right-greenmarketingstrategy $>$ accessed 8 January 2018.

Kaplan Brent, Gelioni Brett, Reed Derek, 'A behavioral economic approach to green consumerism: Demand for reusable shopping bags' (2018) 27 BSI 20, $30<\mathrm{https} / /$ doi.org/10.5210/ bsi.v27i0.8003> accessed 11 August 2018.

Kumar Prashant, 'State of green marketing research over 25 years (1990-2014): Literature survey and classification' (2016) 34(1) MIP 137, $158<$ https://doi.org/10.1108/MIP-03-20150061> accessed 6 December 2017.

Kilbourne William, Beckmann Suzanne, 'Review and critical assessment of research on marketing and the environment' (1998) 14 (6) JMM 513, 532. 
Kotler Philip, Keller Kevin Lane 'Marketing Management' (2012) $14^{\text {th }}$ ed. New Jersey: Pearson Education Prentice Hall 386.

Kotler Philip, (2017) 'Philip Kotler: some of my adventures in marketing' (2017) 9(2) JHRM 203, 208 <https://doi.org/10.1108/JHRM-11-2016-0027> accessed 7 February 2018.

Lee Hsiao Ching, Chang Chun Tuan, Cheng Zhao Hong, Chen Yen Ting 'Will and organic label always increase food consumption? It depends on food type and consumer differences in health locus of control' (2018) 63 FQP 88, 96 <https://doi.org/10.1016/j.foodqual.2017.08.002> accessed 28 August 2018.

Leonidou Constantinos, Leonidou Leonidas, 'Research into environmental marketing management: a bibliographic analysis' (2011) 45 (1,2) EJM 68, $103<$ <ttps://doi. org/10.1108/03090561111095603> accessed 10 April 2018.

Lu Leslie , Bock Dora , Joseph Mathew, 'Green marketing: what the Millennials buy", (2013) 34 (1) JBS 3, 10 < https://doi.org/10.1108/JBS-05-2013-0036 > accessed 1 June 2018.

Martenson Rita, 'When is green a purchase motive? Different answers from different selves' (2018) 46 (1) IJRDM 21, 33 <https://doi.org/10.1108/IJRDM-11-2016-0228 > accessed 20 July 2018.

Mayer Roger, Davis James, Shoorman David, 'An integrative model of organizational trust' (1995) 20(3) AMR 709, $734<$ https://doi.org/10.5465/amr.1995.9508080335> accessed 29 May 2018.

McDonagh Pierre, Prothero Andrea, 'Sustainability marketing research: past, present and future' (2014) $30 \mathrm{JMM}$ 1186, $1219<$ https://doi.org/10.1080/0267257X.2014.943263> accessed 9 February 2018.

Ministry of Agriculture, Forestry and Rural Development 'Kosovo Green Report 2017' (2017) GK 15,181.

Ministry of Environment and Spatial Planning 'Strategy on Waste Management 2013-2022' (2013) GK 8, 63.

Ministry of Health, 'Administrative Instruction MSH 12/2005 on Labeling of Food Products' (2005) Article 3, GoK 14, 26.

Nguyen The Ninh, Phan Thi Thu Hoai, Cao Tuan Khanh, Nguyen Hoang Viet, 'Green purchase behavior: mitigating barriers in developing countries' (2017) 33 (8) SD 4, $6<$ https://doi. org/10.1108/SD-04-2017-0064> accessed 11 March 2018.

Nielsen Survey Report, 'Doing well by doing good increasingly, consumers care about corporate social responsibility, but does concern convert to consumption?' (2014) <http://www. nielsen.com/content/dam/nielsenglobal/apac/docs/reports/2014/Nielsen-Global-CorporateSocial-Responsibility-Report-June> accessed 26 March 2018.

Official Journal of the European Union (2006) 'Directive 2006/114/EC of the European Parliament and of the Council of 12 December 2006 concerning misleading and comparative advertising (codified version) < https://eur-lex.europa.eu/eli/dir/2006/114/oj> accessed 3 June 2018.

Official Gazette of Assembly of Kosovo, Law No.2004/17 on Consumers Protection (2004) Assembly of Kosova.

Papadas Karlos Konstantinos, Avlonitis George, Carrigan Marylyn, (2017) 'Green marketing orientation : Conceptualization, scale development and validation' (2017) 80 JBR 236, $246<$ https://doi.org/10.1016/j.jbusres.2017.05.024> accessed 28 August 2018.

Pagiaslis Anastasios, Krontalis Athanasios Krystallis, 'Green consumption behavior antecedents: Environmental concern, knowledge, and beliefs' (2014) 31 (5) PM 335, $348<\mathrm{https}$ :// doi.org/10.1002/mar.20698> accessed 22 November 2017. 
Peattie Ken, 'Environmental marketing management: Meeting the green challenge' (1995) University of Michigan: Pitman Publishing.

Peattie Ken, Collins Andrea , 'Guest editorial: perspectives on sustainable consumption' (2009) 33 (2) IJCS 107, $122<$ https://doi.org/10.1111/j.1470-6431.2009.00758.x > accessed 23 February 2018.

Polonsky Michael Jay, 'An introduction to green marketing' (1994) 1(1) EGJ < https://www. uow.edu.au/ sharonb/STS300/market/green/article2.html> accessed 10 December 2017.

Podvorica Hamdi, 'E drejta familjare' (2011) $4^{\text {th }}$ edition Kosovo: University of Prishtina.

Reichheld Frederick, Schefter Phil , 'E-loyalty your secret weapon on the Web' (2000) 78 (4) HBR 105, 113.

Treaty on the Functioning of the European Union (1958) Title XV: Consumer Protection.

Sammer Katharina, Wüstenhagen Rolf 'The influence of eco-labelling on consumer behavior-results of a discrete choice analysis for washing machines' (2006) 15 (3) BSE 185, 199 $<$ https://doi.org/10.1002/bse.522> accessed 11 November 2017.

Yadav Rambalak, Pathak Govind Swaroop, 'Young consumers' intention towards buying green products in a developing nation: Extending the theory of planned behavior' (2016) 135 JCP 732, $739<$ https://doi.org/10.1016/j.jclepro.2016.06.120> accessed 11 March 2018. 